\title{
Toimijuudestako avaimet sukupuolilukkojen purkamiseen?
}

Hanna Ojala, Tarja Palmu \& Jaana Saarinen (toim.). Sukupuoli ja toimijuus koulutuksessa. Vastapaino 2009, 255 sivua

$\mathrm{K}$ äsitteenä toimijuus ohjaa analyysia rakenteista kohti yksilöitä, mutta silti koulutuspoliittiset ideologiat, koulutusjärjestelmän rakenteet ja koulutuksen käytännöt määrittävät ihmisten toimintaa ja toiminnan rajoja koulutusjärjestelmän eri tasoilla päiväkodista aikuiskoulutukseen. Koulutus on yhteiskunnallisen vallankäytön järjestelmä, joka rakentaa ihmisten käsityksiä itsestä, omista kyvyistä ja mahdollisuuksista.

Toimijuuteen ja sukupuoleen liitetyt oletukset konkretisoituvat instituutioissa erilaisina odotuksina, miten tietyissä tilanteissa tulisi toimia. Koulutus antaa vaikutelman sukupuolineutraaliudesta, mutta tytöille ja naisille, pojille ja miehille asetetut odotukset eroavat toisistaan ja rakentavat usein tiedostamattomasti heidän ymmärrystään omasta osaamisesta ja toimintamahdollisuuksista.

Kiinnostus toimijuuden tutkimiseen on voimistunut 1990-luvun lopulta lähtien. Käsitteen teoretisointi on kiinnostanut erityisesti yhteiskuntatieteilijöitä sekä kulttuurin ja feminismin tutkijoita. Kuten kirjan toimittajat toteavat, toimijuuden tutkimisesta on tullut jopa muoti, jonka varjopuoliin kuuluu käsitteen liian väljä käyttö. Käsitettä ei välttämättä määritellä, ja usein sitä käytetään identiteetin, subjektin tai yksilön synonyymina. Ehkä käsitteen määrittelyn sivuuttaminen tulee ymmärrettäväksi, kun lukee teoksen johdantoluvun, jossa kirjoittajat osoittavat sukupuolisen toimijuuden käsitteen monikerroksisuuden.

Johdantoluvussa avataan toimijuuden käsitteen ymmärtäminen feministisessä tutkimuksessa, jossa kyseenalaistetaan käsitys eheästä, ennalta tiedetystä ja rakenteet yksilönä kohtaavasta subjektista. Erilaisia käsityksiä toimijuudesta yhdistää ajatus sen rakentumisesta vuorovaikutuksessa ja tilanteisesti. Toimijuus on dynaaminen käsite, joka rakentuu diskurssiivisesti mutta samalla myös materiaaliset seikat määrittävät sitä: ihmisen toimintaa analysoidaan paikantuneena ja tilanteisesti muuttuvana. Sukupuoli käsitteellistetään tekemisenä ja toimintana. Miehet ja naiset eivät liioin muodosta yhtenäisiä ryhmiä, vaan muut kollektiiviset erot, kuten yhteiskuntaluokka, seksuaalinen suuntautuminen, ikä ja etninen tausta, muokkaavat niissä molemmissa sukupuolten sisäisiä järjestyksiä.

Kirjan toimittajat kertovat pyrkineensä tuomaan uusia keskustelunavauksia kasvatustieteen kentälle (s.11). He ovat kiinnostuneita, miten sukupuoli määrittelee toiminnan mahdollisuuksia ja rajoituksia ja toimijuuden tuntoa sekä käsitteen käyttökelpoisuutta koulutuksen su- kupuolistuneiden käytäntöjen tutkimiselle. Loppuosan koulutuspolitiikkaa ja koulutuksen sukupuolistavia käytäntöjä käsittelevät luvut konkretisoivat toimijuuden käsitteen käyttöä kolmella tasolla: makrotasolla analysoidaan muun muassa diskurssiivisia rakenteita, mesotasolla instituutioiden ja organisaatioiden käytäntöjä ja mikrotasolla yksilöiden omia toimijuutensa määrittelyitä.

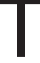
eokseen kirjoittajakaartiin kuuluu 11 naista. Se jakautuu kolmeen osioon, joista ensimmäisessä tarkastellaan sukupuolta ja toimijuutta koulutuspoliittisissa teksteissä ja diskursseissa. Koulutuksen yhteiskunnalliseen ohjaamisen ja hallintaan sisältyy usein tunnistamattomiksi jääviä mekanismeja, jotka säätelevät koulutuspoliittista päätöksentekoa, ihmisten toimintaa ja vuorovaikutusta. Kirsti Lempiäinen problematisoi kiinnostavasti, miten abstraktit, sukupuolineutraaleilta vaikuttavat EU:n koulutuspoliittisten asiakirjojen tilastot ja erilaiset indikaattorit toimivat sukupuolisten valtasuhteiden rakentajina. Tietointensiivistä taloutta painottavissa tavoitteissa piirtyy toimijan ideaaliksi tehokas, uudistushaluinen, lakkaamatta itseään kehittävä aktiivinen kansalainen. Koulutuspolitiikkaa merkittävästi suuntaava abstrakti numerotieto kuitenkin sivuuttaa nais- ja mieskansalaisten toimijuuden historiallisesti ja yhteiskunnalli- 
sesti muovautuneet erot samoin kuin kansallisten sukupuoliregiimien merkitykset. Kristiina Brunila tarkastelee toimijuuden mahdollisuuksia ja reunaehtoja koulutusalan tasa-arvotyössä. Tasaarvotyöntekijöiden työtä tukevat ja toisaaalta haastavat sen ammatillistuminen ja muotoutuminen tulostietoisiksi projekteiksi. Diskurssitaituruus voi lisätä toimintatilaa henkilökohtaista innostusta edellyttävässä tasa-arvotyössä, jota leimaa feminismin ja professionaalisen tasa-arvotyön hankala suhde.

oisessa osiossa paneudutaan viime vuodet julkisessa keskustelussa pyörineisiin teemoihin sukupuolen kahtiajaosta, jossa on tyypillistä tyttöjen ja poikien dikotominen vastakkainasettelu. Näitä jumiutuneita diskursseja asetetaan artikkeleissa historiallisiin ja koulutuspoliittisiin kehyksiin osoittaen samalla, miten diskurssiiviset merkitykset rajaavat tai mahdollisesti myös avaavat tyttöjen ja poikien toiminnan mahdollisuuksia. Annukka Jauhiainen lähestyy aihetta suomalaisen koulutuksen historian näkökulmasta keskittyen perus- ja lukiokoulutuksen keskusteluihin siitä, pitäisikö tyttöjä ja poikia kouluttaa yhdessä vai erikseen. Nykyisten eriyttämisdiskurssien "uuden tulemisen" pohjalta löytyy keskustelujen pitkä linja, jossa erillis- ja yhteisopetuksen perusteluihin ovat kytkeytyneet paitsi koulutettavien ikävaihe ja sosiaaliluokka myös koulutuksen taloudelliset ehdot. Elina Lahelman artikkelin lähtökohtana on koulutuspoliittisessa keskustelussa toistuvasti esitetty huoli poikien koulumenestyksestä. Tässä huolipuheessa sukupuoleen liittyviä ominaisuuksia yliyksinker- taistetaan, tyttöjä vähätellään ja naisopettajia syyllistetään. On tärkeää, että tarkastelu ulotetaan peruskoulun jälkeiseen vaiheeseen, sillä tyttöjen keskimäärin parempi koulumenestys ei välttämättä takaa heille poikien kanssa yhtäläisesti jatkokoulutukseen pääsyä tai koulutustasoa vastaavia ansioita. Liisa Tainio tarkastelee artikkelissaan keskustelumenetelmän avulla yläkoulun luokkahuoneen vuorovaikutusta tuoden esiin kielellisiä tapoja, joilla koulun arjessa rakennetaan sukupuolta.

Kolmannessa osiossa koulutusinstituutioita tarkastellaan naisten työympäristönä. Artikkelit pohjaavat naisten kokemustietoon, joka asetetaan laajempiin yhteiskunnallisiin kehyksiin. Outi Ylitapio-Mäntylä pohtii päiväkodin kasvatuskulttuurin sukupuolistavia käytäntöjä lastentarhanopettajan toimintamahdollisuuksien näkökulmasta. Jaana Saarisen kohteena ovat tutkijanaisten identiteetin rakentuminen ja toimijuus yliopistotyössä, jonka naisistuessa tutkijan työn reunaehdot ovat tiukentuneet. Autonomisesta, kokopäiväisestä ja kunnollisen toimeentulon tarjoavasta työstä on kilpailuyliopistossa tullut epävarmaa ja taloudellisestikin epävakaata pätkätyötä, jossa joutuu jatkuvasti todistelemaan kilpailukykyään. Tuoreen näkökulman tarjoaa Leena Kosken ja Silva Tedren artikkeli, jossa lähestytään tutkijanaisia iän ja ruumiillisuuden näkökulmista tarkastelemalla sukupuolistuneen ruumiillisen toimijan rakentumista yliopiston kulttuurisissa, sosiaalisissa ja fyysisissä tiloissa ja käytännöissä. Yliopistossa tieteen tila ruumiillistuu (mies)professorissa ja konkretisoituu yliopiston maskuliinisissa käytännöis- sä, symboleissa ja ideaaleissa. Naisten autonomista tilaa ja toimijuutta rajoittaa sukupuolen lisäksi ikä: eri ikävaiheisiin kytkeytyy kulttuurisesti määrittyvä status ja siihen liittyvät oikeudet ja velvollisuudet. Toimijuudessa ikä asettuu ristiriitaisesti sukupuoleen. Ikä kylläkin vapauttaa sukupuolen taakoista, mutta juuri kun autonominen toimijuus on avautumassa vanheneminen alkaa rajata toiminnan tilaa, koska mahdollisuudet tutkimusrahoitukseen ja urasuunnitelmiin niukkenevat.

Teoksessa avataan toimijuuden käsitteen käyttökelpoisuus eri tarkastelutasoilla. Tekstien perusteella tasa-arvoiseen toimijuuteen on vielä matkaa. Refleksiivisyys mahdollistaa sukupuolen määrittelyjen uudistamisen, mutta ei välttämättä tarjoa vapautta sukupuolesta. Ymmärrys sukupuolesta voi toimia myös perinteisten sukupuolisten käytäntöjen ylläpitäjänä. Esimerkiksi perheissä tunnistetaan yleinen tasa-arvodiskurssi kotitöiden tasapuolisesta jakamisesta, mutta siitä huolimatta perinteisten roolien mukaan nainen laitaa ruuan, hoitaa lapset ja mies korjaa auton. Koulumaailmassakin tasa-arvo ja yhdenvertaisuus on kirjattu lainsäädäntöön, mutta se ei silti vaikuta koulun arjen sukupuolistaviin käytäntöihin. Siksi koulutuksen rakenteellisten uudistusten ohella tarvitaan koulutuksen arjen käytäntöjen ja koulutusinstituutioissa toimivien kokemusten tutkimusta. Sitä kautta voi löytyä ymmärrystä vastustaa arjen sukupuolistavien rutiinien ja tottumusten taivuttavaa voimaa ja luoda uudenlaisia toiminnan mahdollisuuksia.

\section{Marjo Vuorikoski}

